\title{
Distillers Dried Grain as a Partial Replacement for Wheat Flour in the Diet of Juvenile Rockfish Sebastes schlegeli
}

\author{
Jin Choi, Md Mostafizur Rahman and Sang-Min Lee* \\ Department of Marine Bioscience and Technology, Gangneung-Wonju National University, Gangneung 210-702, Korea
}

\begin{abstract}
A 9-week feeding experiment was designed to test the effects of the dietary inclusion of distillers dried grain (DDG) on the growth performance, body composition, and antioxidant activity of juvenile rockfish Sebastes schlegeli. Five isonitrogenous and isocaloric diets were formulated to contain 0\% DDG (DDG0), 7\% and 14\% DDG from rice (diets DDG-R7 and DDG-R14, respectively), as well as 7\% and 14\% DDG from rice and wheat flour (diets DDG-RW7 and DDG-RW14, respectively). Three replicate groups of juvenile rockfish averaging $68.0 \pm 0.4 \mathrm{~g}$ were fed one of the diets to apparent satiation twice a day. Survival, weight gain, feed efficiency, and the protein efficiency ratio of fish were not affected by dietary DDG $(P>0.05)$. Proximate and amino acid compositions of the whole body were not affected by dietary DDG $(P>0.05)$. Plasma total protein, glucose, total cholesterol, glutamate oxaloacetate transaminase, glutamate pyruvate transaminase, phospholipid, and triglyceride were not affected by dietary DDG $(P$ $>0.05$ ). Radical scavenging activity on 1,1-diphenyl-2-picryl-hydrazyl (DPPH) in the plasma of rockfish fed the DDG-RW14 diet was higher than that of fish fed the DDG0 diet $(P<0.05)$. Hydroxyl radical scavenging activity in the liver of rockfish fed diets containing DDG was higher than that of fish fed the DDG0 diet $(P<0.05)$. Alkyl radical scavenging activity in the liver of rockfish fed the DDG-R7 diet was higher than that of fish fed the DDG0 diet $(P<0.05)$. These results suggest that DDG is a suitable ingredient for the partial replacement of wheat flour and can be used at a rate of up to $14 \%$ in the diet without incurring negative effects on the growth performance or body chemical composition of juvenile rockfish.
\end{abstract}

Key words: Distillers dried grain, Dietary ingredient, Wheat flour, Rockfish, Growth

\section{Introduction}

The aquaculture industry is playing an increasingly important role in meeting the demand for fish for human consumption. The rapid development of the aquaculture industry is the most pronounced in Asia, which contributes about $89 \%$ of the global aquaculture production (Karunasagar, 2012). This increase in aquaculture production has resulted in an increased dependency on use of formulated diets for fish. Feeds used in aquaculture must be nutritionally suitable, but a great emphasis is being placed on the cost of feedstuffs as they account for about $50 \%$ of the total farm production costs for most aquatic species (Coyle et al., 2004). Due to the deficiency and ex- penditure of imported ingredients such as fish meal, soybean meal, and wheat flour, identifying alternative ingredients for use in markets that import much of their grain is important. Several scientific studies have examined alternative protein sources to fish meal, but limited studies on alternative carbohydrate sources have been published. Recently, because of the increasing expense and uncertain availability of many ingredients such as wheat flour (Rahman et al., 2013), we decided to investigate alternative carbohydrate sources. Replacement of wheat flour with less-expensive energy sources would be beneficial in reducing feed costs.

\section{http://dx.doi.org/10.5657/FAS.2014.0085}

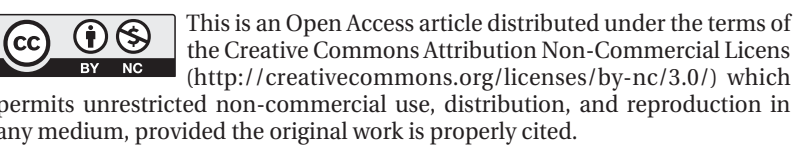

Received 09 September 2013; Revised 17 September 2013

Accepted 30 October 2013

*Corresponding Author

E-mail: smlee@gwnu.ac.kr 
Distillers dried grain (DDG), a cereal by-product of the distillation process, is becoming an increasingly important ingredient due to its comparative affordability and rich vitamin and mineral contents (Cromwell et al., 1993). Traditionally, DDG has been utilized as a protein supplement (about $30 \%$ crude protein) in terrestrial animal feeds (De Godoy et al., 2009; Lim et al., 2009; Saunders and Rosentrater, 2009). DDG also has great potential to be used as a fish feed ingredient because of its relatively high protein content comparable to other grains used in fish feed production, and because it is very economically priced (Zhou et al., 2010; Li et al., 2011). Incorporation of DDG into the diet may be less expensive than other ingredients such as wheat flour (Rahman et al., 2013). Belyea et al. (2004) reported that this by-product of the drygrind, resulting from the yeast fermentation of cereal grains, is a valuable feed ingredient. Yamamoto et al. (2004) reported that fermentation is actually a cost-effective and suitable technique for drying out moist products, with minimal nutrient decline. Moreover, the fermentation of plant ingredients was demonstrated to induce substantial inactivation of antinutritional factors (Reddy and Pierson, 1994), improve the nutritional quality (Canella et al., 1984), increase the apparent digestibility (Kiers et al., 2000), and extend the shelf life of the resulting product (Skrede and Nes, 1988). DDG has been shown to be a viable potential substitute protein and/or energy source pertaining to aquafeed (Chevanan et al., 2010). Several studies have demonstrated that corn-based DDG is a suitable aquaculture dietary component on the basis of the growth performance of fish such as rainbow trout (Cheng and Hardy, 2004), channel catfish (Webster et al., 1993; Li and Robinson, 2007; Lim et al., 2009), and tilapia (Wu et al., 1997; Coyle et al., 2004; Lim et al., 2007; Schaeffer et al., 2009).

Rockfish Sebastes schlegeli is a highly popular and commercially important aquaculture species in Asia, largely due to its desirable characteristics for culture, including high tolerance to low water temperature, acceptance of dry pelleted feed, high stocking density, consumer preference, ease of spawning, and hatchery productivity, as well as having a good market price. This study was conducted to evaluate the effect of replacing wheat flour with DDG on the overall nutritional health of rockfish.

\section{Materials and Methods}

\section{Experimental diets}

Proximate and essential amino acid compositions of the ingredients used in the experimental diets are shown in Table 1. Ingredients and chemical compositions of the experimental diets are presented in Table 2. Five isonitrogenous and isocaloric diets were formulated to contain 0\% DDG (DDG0), $7 \%$ and $14 \%$ DDG from rice (diets DDG-R7 and DDG-R14, respectively), as well as $7 \%$ and $14 \%$ DDG from a mixture of rice and wheat flour (diets DDG-RW7 and DDG-RW14, respectively). Pollack fish meal was used as the primary protein source. Fish oil was used as the lipid source. DDG was sourced as a by-product of Makgeolli (a traditional alcoholic beverage native to Korea) production, and was produced by filtration of an aqueous mixture of fermented rice and/or wheat flour with Aspergillus oryzae and yeasts. DDG was dried at $60^{\circ} \mathrm{C}$ for 24 $\mathrm{h}$ before incorporation into the experimental diets. All ingre-

Table 1. Chemical composition of ingredients used in the experimental diets

\begin{tabular}{|c|c|c|c|c|}
\hline & \multicolumn{4}{|c|}{ Ingredients } \\
\hline & Fish meal & Wheat flour & DDG-R* & DDG-RW \\
\hline \multicolumn{5}{|c|}{ Proximate composition $(\% \mathrm{DM})$} \\
\hline Dry matter & 95.8 & 89.3 & 98.2 & 98.1 \\
\hline Crude protein & 75.3 & 19.3 & 19.1 & 28.4 \\
\hline Crude lipid & 8.8 & 3.9 & 7.8 & 3.5 \\
\hline Ash & 14.6 & 2.2 & 0.5 & 0.6 \\
\hline \multicolumn{5}{|c|}{ Essential amino acid composition ( $\%$ in protein) } \\
\hline Arg & 6.7 & 5.7 & 6.9 & 7.9 \\
\hline His & 2.3 & 2.9 & 2.0 & 2.3 \\
\hline Ile & 4.5 & 2.3 & 3.6 & 3.6 \\
\hline Leu & 8.3 & 6.0 & 8.0 & 7.9 \\
\hline Lys & 8.8 & 3.7 & 3.1 & 3.6 \\
\hline Met + Cys & 5.1 & 2.8 & 3.4 & 3.5 \\
\hline Phe + Tyr & 8.1 & 6.8 & 10.8 & 10.3 \\
\hline Thr & 4.8 & 3.5 & 4.7 & 4.7 \\
\hline Val & 4.5 & 3.2 & 5.8 & 5.4 \\
\hline
\end{tabular}

DDG, distillers dried grain.

*Residue obtained by filtration of an aqueous mixture of fermented rice with Aspergillus oryzae and yeasts produced from I Makgeolli factory (Incheon, Korea), ${ }^{\dagger}$ Residue obtained by filtration of an aqueous mixture of fermented rice and wheat flour with Aspergillus oryzae and yeasts produced from $\mathrm{P}$ Makgeolli factory (Pocheon, Korea). 
dients were thoroughly mixed and pellets were prepared using a laboratory moist pelleting machine. The pellets were dried at room temperature for $48 \mathrm{~h}$ and then ground into desirable particle sizes. All diets were stored at $-30^{\circ} \mathrm{C}$ until use.

\section{Experimental fish and feeding conditions}

Juvenile rockfish were transported from a private hatchery (Namhae, Korea) to the Marine Biology Center for Research and Education at Gangneung-Wonju National University (Gangneung, Korea) and were acclimated to laboratory conditions by feeding with commercial pellets for 2 weeks before starting the feeding trial. After the acclimation period, 450 juvenile rockfish (mean body weight, $68.0 \pm 0.4 \mathrm{~g}$ ) were randomly distributed into 15 400-L cylindrical plastic tanks (300 $\mathrm{L}$ water volume) at a density of 30 fish per tank. Each experi- mental diet was fed to three groups of fish to visual satiation twice per day (09:00 and 17:00 h) for 9 weeks. Filtered seawater was supplied at a flow rate of $4 \mathrm{~L} / \mathrm{min}$ in each tank, and the mean water temperature and salinity were $20.4 \pm 2.0^{\circ} \mathrm{C}$ and $34 \pm 0.1 \mathrm{ppt}$, respectively. The natural photoperiod was maintained during the feeding trail. Records were kept of daily feed consumption, mortalities, and feeding behavior.

\section{Sample collections and analytical methods}

At the end of each feeding experiment, all of the fish in each tank were collectively weighed after anesthetizing with tricaine methanesulfonate (MS222; Sigma, St. Louis, MO, USA) at a concentration of $100 \mathrm{mg} / \mathrm{L}$ after starvation for $24 \mathrm{~h}$. At the end of the feeding trials, five fish per tank were sampled and stored at $-25^{\circ} \mathrm{C}$ for the analysis of proximate and essen-

Table 2. Ingredients and chemical composition of the experimental diets

\begin{tabular}{|c|c|c|c|c|c|}
\hline \multirow{2}{*}{ Ingredients (\%) } & \multicolumn{5}{|c|}{ Diets } \\
\hline & DDG0 & DDG-R7 & DDG-R14 & DDG-RW7 & DDG-RW14 \\
\hline Pollack fish meal & 60.0 & 60.0 & 60.0 & 60.0 & 60.0 \\
\hline Distillers dried grain powder- $\mathrm{R}^{*}$ & & 7.0 & 14.0 & & \\
\hline Distillers dried grain powder- $\mathrm{RW}^{\dagger}$ & & & & 7.0 & 14.0 \\
\hline Wheat flour & 28.0 & 21.0 & 14.0 & 21.0 & 14.0 \\
\hline Corn gluten meal & 2.0 & 2.0 & 2.0 & 2.0 & 2.0 \\
\hline$\alpha$-Potato-starch & 5.0 & 5.0 & 5.0 & 5.0 & 5.0 \\
\hline Squid liver oil & 2.0 & 2.0 & 2.0 & 2.0 & 2.0 \\
\hline Vitamin premix ${ }^{*}$ & 1.0 & 1.0 & 1.0 & 1.0 & 1.0 \\
\hline Mineral premix ${ }^{\S}$ & 1.0 & 1.0 & 1.0 & 1.0 & 1.0 \\
\hline Stay-C (50\%) & 0.5 & 0.5 & 0.5 & 0.5 & 0.5 \\
\hline Choline salt (50\%) & 0.3 & 0.3 & 0.3 & 0.3 & 0.3 \\
\hline Taurine & 0.2 & 0.2 & 0.2 & 0.2 & 0.2 \\
\hline \multicolumn{6}{|l|}{ Nutrient content (\% DM) } \\
\hline Crude protein & 47.8 & 47.8 & 47.8 & 50.1 & 50.1 \\
\hline Crude lipid & 6.6 & 6.9 & 7.2 & 6.8 & 7.0 \\
\hline Ash & 13.6 & 14.0 & 13.3 & 13.4 & 13.5 \\
\hline $\mathrm{N}$-free extract ${ }^{\natural}$ & 32.0 & 31.3 & 31.7 & 29.7 & 29.5 \\
\hline \multicolumn{6}{|c|}{ Essential amino acid composition (\% in protein) } \\
\hline Arg & 6.7 & 6.6 & 6.5 & 6.5 & 6.8 \\
\hline His & 2.1 & 2.1 & 2.1 & 2.2 & 2.1 \\
\hline Ile & 2.7 & 3.1 & 3.4 & 3.4 & 2.7 \\
\hline Leu & 8.0 & 8.1 & 8.3 & 8.2 & 8.0 \\
\hline Lys & 7.0 & 6.8 & 6.6 & 7.0 & 6.8 \\
\hline Met + Cys & 3.4 & 3.9 & 3.8 & 3.8 & 3.5 \\
\hline Phe + Tyr & 7.0 & 7.1 & 7.2 & 7.0 & 7.0 \\
\hline Thr & 4.5 & 4.6 & 4.7 & 4.7 & 4.6 \\
\hline Val & 3.3 & 3.8 & 4.1 & 4.2 & 3.5 \\
\hline
\end{tabular}

DDG, distillers dried grain.

${ }^{*}$ Residue obtained by filtration of an aqueous mixture of fermented rice with Aspergillus oryzae and yeasts produced from I Makgeolli factory (Incheon, Korea), ${ }^{\dagger}$ Residue obtained by filtration of an aqueous mixture of fermented rice and wheat flour with Aspergillus oryzae and yeasts produced from P Makgeolli factory (Pocheon, Korea), ${ }^{\dagger}$ Vitamin premix contained the following amount which were diluted in cellulose (g/kg premix): DL-a-tocopheryl acetate, 18.8; thiamin hydrochloride, 2.7; riboflavin, 9.1; pyridoxine hydrochloride, 1.8; niacin, 36.4; Ca-D-pantothenate, 12.7; myo-inositol, 181.8; D-biotin, 0.27; folic acid, 0.68; p-aminobenzoic acid, 18.2; menadione, 1.8; retinyl acetate, 0.73 ; cholecalciferol, 0.003 ; cyanocobalamin, $0.003,{ }^{5}$ Mineral premix contained the following ingredients (g/kg premix): $\mathrm{MgSO}_{4} \cdot 7 \mathrm{H}_{2} \mathrm{O}, 80.0 ; \mathrm{NaH}_{2} \mathrm{PO}_{4} \cdot 2 \mathrm{H}_{2} \mathrm{O}, 370.0 ; \mathrm{KCl}, 130.0$; Ferric citrate, 40.0; $\mathrm{ZnSO}_{4} \cdot 7 \mathrm{H}{ }_{2} \mathrm{O}, 20.0 ; \mathrm{Ca}-\mathrm{lactate}, 356.5 ; \mathrm{CuCl}, 0.2$; $\mathrm{AlCl}_{3} \cdot 6 \mathrm{H}_{2} \mathrm{O}, 0.15 ; \mathrm{KI}, 0.15 ; \mathrm{Na}_{2} \mathrm{Se}_{2} \mathrm{O}_{3}, 0.01 ; \mathrm{MnSO}_{4} \cdot \mathrm{H}_{2} \mathrm{O}, 2.0 ; \mathrm{CoCl}_{2} \cdot 6 \mathrm{H}_{2} \mathrm{O}, 1.0$, "Nitrogen-free extract = 1,000 - (crude protein + crude lipid + ash). 
tial amino acid composition. Proximate composition was analyzed according to standard methods (Association of Official Analytical Chemists, 1995). Crude protein was determined by the Kjeldahl method using an auto Kjeldahl System (Buchi, Flawil, Switzerland). Crude lipid was analyzed with ether extraction in a Soxhlet extractor (SER 148; VELP Scientifica, Milano, Italy). Moisture was determined using a drying oven at $105^{\circ} \mathrm{C}$ for $6 \mathrm{~h}$, and the ash content was determined after combustion at $550^{\circ} \mathrm{C}$ for $4 \mathrm{~h}$ in a muffle furnace. Amino acid compositions of the experimental diets and whole body of fish were analyzed with acid hydrolysis with $6 \mathrm{~N} \mathrm{HCL}$ (reflux for $23 \mathrm{~h}$ at $110^{\circ} \mathrm{C}$ ) using an automatic amino acids analyzer (Hitachi, Tokyo, Japan).

\section{Blood chemistry}

Blood samples were taken from the caudal veins of five fish per tank using heparinized syringes. Plasma was collected after centrifugation at 7,500 $\mathrm{g}$ for $10 \mathrm{~min}$, and plasma was separated and stored at $-70^{\circ} \mathrm{C}$ for chemical analysis. Plasma total protein, glucose, total cholesterol, glutamate oxaloacetate transaminase (GOT), glutamate pyruvate transaminase (GPT), phospholipid, and triglyceride concentrations were determined using a clinical investigation commercial kit (Asan Pharmaceutical Co., Seoul, Korea).

\section{Radical scavenging activities}

At the end of the feeding trials, five fish per tank were sampled and stored at $-75^{\circ} \mathrm{C}$ for antioxidant activity analysis. Samples were extracted from plasma and liver, and were homogenized (Wiggenhauser, Berlin, Germany) with extract buffer in $5 \mathrm{mM}$ Tris- $\mathrm{HCl}$ and $35 \mathrm{mM}$ glycine $(\mathrm{pH} 8.4)$ followed by centrifugation $\left(13,000 \mathrm{~g}\right.$ for $10 \mathrm{~min}$ at $\left.4^{\circ} \mathrm{C}\right)$. The supernatant was then collected and analyzed for its radical scavenging activity.

\section{Assays of DPPH, hydroxyl, and alkyl radical scav- enging activities on an electron spin resonance spectrometer}

Evaluation of 1,1-diphenyl-2-picryl-hydrazyl (DPPH) radical scavenging activity was performed using the method described by Nanjo et al. (1995). A 30- $\mu \mathrm{L}$ peptide solution (or ethanol itself, as the control) was added to $30 \mu \mathrm{L}$ of DPPH (60 $\mu \mathrm{mol} / \mathrm{L}$ ) in ethanol solution. After mixing vigorously for $10 \mathrm{~s}$, the solution was transferred to a $100-\mu \mathrm{L}$ quartz capillary tube, and the scavenging activity of the peptides on DPPH radicals was determined using a spectrometer (JEOL Ltd., Tokyo, Japan). After $2 \mathrm{~min}$, the spin adduct was determined on an electron spin resonance (ESR) spectrometer. The measurement conditions were as follows: magnetic field, $336.5 \pm 5 \mathrm{mT}$; power, $5 \mathrm{~mW}$; modulation frequency, $9.41 \mathrm{GHz}$; amplitude, 1 $\times 1,000$; and sweep time, $30 \mathrm{~s}$.
Hydroxyl radicals were generated by an iron-catalyzed Fenton Haber-Weiss reaction and reacted rapidly with electron spin trap 5,5-dimethyl-1-pyrroline- $N$-oxide (DMPO) (Rosen and Rauckman, 1984). The resultant DMPO-OH adducts were assessable with an ESR spectrometer. The peptide solution $(20 \mu \mathrm{L})$ was blended with DMPO $(0.3 \mathrm{M}, 20 \mu \mathrm{L})$, $\mathrm{FeSO}_{4}(10 \mathrm{mmol} / \mathrm{L}, 20 \mu \mathrm{L})$, and $\mathrm{H}_{2} \mathrm{O}_{2}(10 \mathrm{mM}, 20 \mu \mathrm{L})$ in a phosphate buffer solution ( $\mathrm{pH} 7.4)$, and then transferred to a $100-\mu \mathrm{L}$ quartz capillary tube. After $2.5 \mathrm{~min}$, the ESR spectrum was recorded using an ESR spectrometer. Experimental conditions were as follows: magnetic field, $336.5 \pm 5 \mathrm{mT}$; power, $1 \mathrm{~mW}$; modulation frequency, $9.41 \mathrm{GHz}$; amplitude, $1 \times 200$; and sweep time, $4 \mathrm{~min}$.

Alkyl radicals were generated by 2, 2-azobis-(2-amidinopropane)-hydrochloride (AAPH). The phosphate-buffered saline $(\mathrm{pH}$ 7.4) reaction mixtures included $10 \mathrm{mmol} / \mathrm{L} \mathrm{AAPH}$, $10 \mathrm{mmol} / \mathrm{L} 4-\mathrm{POBN}$, and known concentrations of the sample $(100 \mu \mathrm{g} / \mathrm{mL})$. The mixtures were incubated at $37^{\circ} \mathrm{C}$ in a water bath for $30 \mathrm{~min}$ (Hiramoto et al., 1993), then transferred to a capillary tube. The spin adduct was recorded using a spectrometer (JEOL Ltd.). The measurement conditions were as follows: modulation frequency, $100 \mathrm{kHz}$; microwave power, $10 \mathrm{~mW}$; microwave frequency, 9,441 MHz; magnetic field, $336.5 \pm 5 \mathrm{mT}$; and sweep time, $30 \mathrm{~s}$.

DPPH, hydroxyl, and alkyl radical scavenging activities (RSA) were computed according to the following equation in which $H$ and $H_{0}$ were the relative peak heights of radical signals, with and without sample, respectively.

$$
\operatorname{RSA}(\%)=\frac{(1-H)}{H_{0}} \times 100
$$

\section{Statistical analysis}

The data were subjected to one-way analysis of variance (ANOVA) using SPSS version 18.0 (SPSS Inc., Chicago, IL, USA). Significant differences $(P<0.05)$ among the means were determined using a Duncan's multiple range test (Duncan, 1955). The data are presented as the mean $\pm \mathrm{SE}$ of the three replicate groups.

\section{Results}

Growth performance, feed utilization, and morphological parameters of juvenile rockfish fed the experimental diets containing DDG are presented in Table 3. Survival, weight gain, feed efficiency, daily feed intake, daily protein intake, and protein efficiency ratio of fish were not affected by dietary DDG additions $(P>0.05)$. Condition factor and hepatosomatic index of the fish were not affected by dietary DDG additions $(P>0.05)$. The results of body composition and essential amino acid composition of juvenile rockfish fed the experimental diets are presented in Table 4. Proximate and 
Table 3. Growth performance, feed utilization and morphological parameters of juvenile rockfish fed the experimental diets for 9 weeks

\begin{tabular}{|c|c|c|c|c|c|}
\hline & \multicolumn{5}{|c|}{ Diets } \\
\hline & DDG0 & DDG-R7 & DDG-R14 & DDG-RW7 & DDG-RW14 \\
\hline Initial body weight ( $\mathrm{g} / \mathrm{fish})$ & $67.4 \pm 0.87^{\text {ns }}$ & $68.0 \pm 0.07$ & $68.4 \pm 0.12$ & $67.8 \pm 0.10$ & $68.4 \pm 0.23$ \\
\hline Survival & $100^{\mathrm{ns}}$ & $93 \pm 3.6$ & $96 \pm 3.0$ & $99 \pm 1.0$ & $96 \pm 3.0$ \\
\hline Mean weight gain (g/fish) & $69.7 \pm 0.79^{\text {ns }}$ & $65.8 \pm 1.79$ & $69.9 \pm 6.28$ & $70.9 \pm 10.23$ & $65.1 \pm 0.35$ \\
\hline Feed efficiency $(\%)^{*}$ & $72 \pm 0.8^{\mathrm{ns}}$ & $68 \pm 1.5$ & $68 \pm 1.2$ & $79 \pm 11.0$ & $66 \pm 0.8$ \\
\hline Daily feed intake $(\%)^{\dagger}$ & $1.55 \pm 0.02^{\mathrm{ns}}$ & $1.53 \pm 0.10$ & $1.55 \pm 0.01$ & $1.43 \pm 0.08$ & $1.54 \pm 0.03$ \\
\hline Daily protein intake $(\%)^{\star}$ & $0.74 \pm 0.01^{\mathrm{ns}}$ & $0.73 \pm 0.05$ & $0.74 \pm 0.01$ & $0.72 \pm 0.04$ & $0.77 \pm 0.01$ \\
\hline Protein efficiency ratio & $1.05 \pm 0.01^{\text {ns }}$ & $1.42 \pm 0.03$ & $1.42 \pm 0.03$ & $1.57 \pm 0.22$ & $1.32 \pm 0.02$ \\
\hline Condition factor & $1.6 \pm 0.02^{\mathrm{ns}}$ & $1.7 \pm 0.05$ & $1.6 \pm 0.01$ & $1.6 \pm 0.04$ & $1.6 \pm 0.03$ \\
\hline Hepatosomatic index ${ }^{* *}$ & $3.9 \pm 0.07^{\mathrm{ns}}$ & $3.9 \pm 0.11$ & $4.2 \pm 0.14$ & $3.9 \pm 0.18$ & $4.0 \pm 0.26$ \\
\hline
\end{tabular}

Values are presented as mean \pm SE of triplicate groups.

DDG, distillers dried grain; ns, not significant $(P>0.05)$.

${ }^{*}$ Feed efficiency $=$ wet weight gain $\times 100 /$ feed intake, ${ }^{\dagger}$ Daily feed intake $=$ feed intake $\times 100 /[($ initial fish wt. + final fish wt. + dead fish wt.) $\times$ days reared/2], ${ }^{\ddagger}$ Daily protein intake $=$ protein intake $\times 100 /[$ (initial fish wt. + final fish wt. + dead fish wt. $) \times$ days reared $\left./ 2\right],{ }^{5}$ Protein efficiency ratio $=($ wet weight gain $/$ protein intake) $\times 100,{ }^{~}$ Condition factor $=\left[\right.$ fish weight $(\mathrm{g}) /$ fish length $\left.(\mathrm{cm})^{3}\right] \times 100,{ }^{* *}$ Hepatosomatic index $=($ liver weight/body weight $) \times 100$.

Table 4. Proximate and essential amino acid composition of the whole body in juvenile rockfish fed the experimental diets for 9 weeks

\begin{tabular}{lccccc}
\hline & & & Diets & & \\
\cline { 2 - 6 } & DDG0 & DDG-R7 & DDG-R14 & DDG-RW7 & DDG-RW14 \\
\hline Proximate composition (\%) & & & & & \\
Moisture & $67.0 \pm 0.21^{\text {ns }}$ & $66.4 \pm 1.23$ & $65.0 \pm 0.21$ & $66.4 \pm 0.84$ & $65.7 \pm 0.37$ \\
Crude protein & $17.7 \pm 0.14^{\text {ns }}$ & $18.2 \pm 0.50$ & $18.8 \pm 0.38$ & $18.3 \pm 0.68$ & $18.6 \pm 0.80$ \\
Crude lipid & $8.5 \pm 0.06^{\text {ns }}$ & $8.1 \pm 0.06$ & $8.4 \pm 0.19$ & $8.3 \pm 0.19$ & $8.5 \pm 0.20$ \\
Ash & $4.5 \pm 0.02^{\text {ns }}$ & $5.2 \pm 0.01$ & $4.9 \pm 0.28$ & $4.6 \pm 0.38$ & $5.0 \pm 0.15$ \\
Essential amino acids (\% in protein) & & & & & \\
Arg & $7.0 \pm 0.07^{\text {ns }}$ & $6.9 \pm 0.09$ & $6.9 \pm 0.12$ & $6.8 \pm 0.03$ & $7.0 \pm 0.10$ \\
His & $2.1 \pm 0.03^{\text {ns }}$ & $2.1 \pm 0.03$ & $2.2 \pm 0.06$ & $2.2 \pm 0.03$ & $2.1 \pm 0.00$ \\
Ile & $2.8 \pm 0.17^{\text {ns }}$ & $3.0 \pm 0.23$ & $3.1 \pm 0.23$ & $3.3 \pm 0.17$ & $2.9 \pm 0.29$ \\
Leu & $7.3 \pm 0.18^{\text {ns }}$ & $7.4 \pm 0.15$ & $7.5 \pm 0.18$ & $7.6 \pm 0.09$ & $7.2 \pm 0.07$ \\
Lys & $8.1 \pm 0.19^{\text {ns }}$ & $8.2 \pm 0.12$ & $8.2 \pm 0.17$ & $8.2 \pm 0.03$ & $7.9 \pm 0.09$ \\
Met + Cys & $3.9 \pm 0.07^{\text {ns }}$ & $3.9 \pm 0.06$ & $3.9 \pm 0.03$ & $4.1 \pm 0.12$ & $3.8 \pm 0.03$ \\
Phe + Tyr & $6.7 \pm 0.12^{\text {ns }}$ & $6.8 \pm 0.12$ & $6.7 \pm 0.10$ & $7.0 \pm 0.15$ & $6.6 \pm 0.10$ \\
Thr & $4.5 \pm 0.03^{\text {ns }}$ & $4.6 \pm 0.03$ & $4.6 \pm 0.06$ & $4.7 \pm 0.03$ & $4.5 \pm 0.03$ \\
Val & $3.3 \pm 0.19^{\text {ns }}$ & $3.4 \pm 0.22$ & $3.6 \pm 0.24$ & $3.7 \pm 0.15$ & $3.4 \pm 0.26$ \\
\hline
\end{tabular}

Values are presented as mean \pm SE of triplicate groups.

DDG, distillers dried grain; $n s$, not significant $(P>0.05)$.

Table 5. Hematological parameters of the plasma of juvenile rockfish fed the experimental diets for 9 weeks

\begin{tabular}{lrrrrr}
\hline & \multicolumn{3}{c}{ Diets } & & \\
\cline { 2 - 6 } & \multicolumn{1}{c}{ DDG0 } & DDG-R7 & DDG-R14 & DDGRW7 & DDG-RW14 \\
\hline Total protein $(\mathrm{g} / \mathrm{L})$ & $40.0 \pm 1.1^{\text {ns }}$ & $41.0 \pm 2.2$ & $41.0 \pm 0.5$ & $38.0 \pm 2.4$ & $40.0 \pm 0.9$ \\
Glucose $(\mathrm{mmol} / \mathrm{L})$ & $3.5 \pm 2.1^{\text {ns }}$ & $1.5 \pm 0.1$ & $2.8 \pm 0.6$ & $2.8 \pm 0.6$ & $4.7 \pm 1.4$ \\
Total Cholesterol (mmol/L) & $14.3 \pm 0.5^{\text {ns }}$ & $13.0 \pm 0.8$ & $13.4 \pm 0.4$ & $13.0 \pm 1.7$ & $13.2 \pm 0.5$ \\
GOT (IU/L) & $1.0 \pm 1.0^{\text {ns }}$ & $3.0 \pm 1.2$ & $2.3 \pm 0.9$ & $3.0 \pm 1.5$ & $2.0 \pm 0.6$ \\
GPT (IU/L) & $1.0 \pm 0.9^{\text {ns }}$ & $2.0 \pm 0.6$ & $1.3 \pm 0.3$ & $4.3 \pm 2.4$ & $1.3 \pm 0.3$ \\
Phospholipid (g/L) & $10.5 \pm 0.3^{\text {ns }}$ & $9.8 \pm 0.8$ & $10.8 \pm 0.1$ & $9.7 \pm 1.5$ & $10.2 \pm 0.3$ \\
Triglyceride (mmol/L) & $4.8 \pm 0.3^{\text {ns }}$ & $4.2 \pm 0.8$ & $6.8 \pm 0.8$ & $4.5 \pm 1.8$ & $5.9 \pm 0.8$ \\
\hline
\end{tabular}

Values are presented as mean \pm SE of triplicate groups.

DDG, distillers dried grain; GOT, lutamate oxaloacetate transaminase; GPT, glutamate pyruvate transaminase; ns, not significant $(P>0.05)$. 
amino acid compositions of the whole body of juvenile rockfish were not affected by dietary DDG additions $(P>0.05)$. The results of hematological parameters of plasma in juvenile rockfish are shown in Table 5. Plasma contents of total protein, glucose, total cholesterol, GOT, GPT, phospholipid, and triglyceride were not affected by dietary DDG $(P>0.05)$. The results of radical scavenging activities in the plasma and liver of juvenile rockfish are presented in Table 6. DPPH radical scavenging activity in the plasma of fish fed the DDG-RW14 diet was higher than that of fish fed the DDG0 diet $(P<0.05)$. Hydroxyl radical scavenging activity in the plasma of fish was not affected by dietary DDG $(P>0.05)$. Alkyl radical scavenging activity in the plasma of fish fed diets containing DDG was not statistically different from that of fish fed the DDG0 diet, but alkyl radical scavenging activities of fish fed the DDG-R14 and DDG-RW7 diets were lower than that of fish fed the DDG-R7 diet $(P<0.05)$. DPPH radical scavenging activity in the liver of fish was not affected by dietary DDG $(P$ $>0.05)$. Hydroxyl radical scavenging activity in the liver of fish fed diets containing DDG was higher than that of fish fed the DDG0 diet $(P<0.05)$. Alkyl radical scavenging activity in the liver of fish fed the DDG-R7 diet was higher than that of fish fed the DDG0 diet $(P<0.05)$.

\section{Discussion}

The results of the present study demonstrate that the inclusion of DDG from rice and/or wheat flour, at a rate of up to $14 \%$ DDG, is appropriate for the diet for juvenile rockfish as a partial replacement for wheat flour without reducing growth performance. Li et al. (2010) observed that inclusion

Table 6. Radical scavenging activity of the plasma and liver of juvenile rockfish fed the experimental diets for 9 weeks

\begin{tabular}{llcl}
\hline \multirow{2}{*}{ Diets } & \multicolumn{3}{c}{ Radical scavenging activity (\%) } \\
\cline { 2 - 4 } & DPPH radical & Hydroxyl radical & Alkyl radical \\
\hline Plasma & & & \\
DDG0 & $60.7 \pm 0.90^{\mathrm{ab}}$ & $46.5 \pm 12.7^{\mathrm{ns}}$ & $63.4 \pm 1.71^{\mathrm{ab}}$ \\
DDG-R7 & $58.5 \pm 0.65^{\mathrm{a}}$ & $52.8 \pm 3.9$ & $66.3 \pm 1.55^{\mathrm{b}}$ \\
DDG-R14 & $58.3 \pm 0.75^{\mathrm{a}}$ & $43.9 \pm 2.6$ & $59.5 \pm 0.89^{\mathrm{a}}$ \\
DDG-RW7 & $64.3 \pm 1.85^{\mathrm{bc}}$ & $38.4 \pm 0.05$ & $61.5 \pm 0.79^{\mathrm{a}}$ \\
DDG-RW14 & $67.7 \pm 0.95^{\mathrm{c}}$ & $52.9 \pm 2.75$ & $63.5 \pm 2.16^{\mathrm{ab}}$ \\
Liver & & & \\
DDG0 & $83.7 \pm 1.00^{\mathrm{ns}}$ & $26.7 \pm 3.05^{\mathrm{a}}$ & $70.2 \pm 0.05^{\mathrm{a}}$ \\
DDG-R7 & $84.1 \pm 2.47$ & $53.2 \pm 3.60^{\mathrm{bc}}$ & $76.2 \pm 0.20^{\mathrm{b}}$ \\
DDG-R14 & $85.4 \pm 2.50$ & $66.3 \pm 1.19^{\mathrm{d}}$ & $71.4 \pm 2.15^{\mathrm{a}}$ \\
DDG-RW7 & $87.4 \pm 0.85$ & $48.3 \pm 1.37^{\mathrm{b}}$ & $70.1 \pm 0.15^{\mathrm{a}}$ \\
DDG-RW14 & $87.0 \pm 2.17$ & $57.4 \pm 1.19^{\mathrm{c}}$ & $74.7 \pm 1.70^{\mathrm{ab}}$ \\
\hline
\end{tabular}

Values (mean $\pm \mathrm{SE}$ of three replications) in the same column not sharing a common superscript are significantly different $(P<0.05)$.

DDG, distillers dried grain; $\mathrm{ns}$, not significant $(P>0.05)$. of corn-based DDG in the diet of channel catfish improved weight gain as well as the feed efficiency ratio compared to an all plant-protein diet (control). Several scientific studies have demonstrated that relatively high levels of corn-based DDG could be used in channel catfish diets without adversely minimizing fish growth performance (Robinson and Li, 2008). Previous studies have shown that corn-based DDG could be used to partially replace soybean meal in channel catfish diets (Webster et al., 1993). Lim et al. (2007) found that up to $20 \%$ corn-based DDG could be included in the diet of Nile tilapia Oreochromis niloticus as a partial replacement for soybean meal and cornmeal without affecting growth performance. Corn-based DDG was found to be successfully utilized in rainbow trout diets (Randall and Drew, 2010; Barnes et al., 2012). Schaeffer et al. (2011) indicated that corn-based DDG combined with soybean meal could be utilized in the yellow perch diet without compromising growth performance. Furthermore, the inclusion of corn-based DDG in the diet might improve palatability of the sunshine bass diet (Thompson et al., 2008). The satisfactory growth performance of freshwater fishes fed diets containing corn-based DDG is attributable to several factors, including improved palatability (Thompson et al., 2008), digestibility (Randall and Drew, 2010), and reduced exposure to anti-nutritional factors (Borgeson et al., 2006). However, limited information is available about the use of rice-based DDG in diets for marine fishes (Rahman et al., 2013). In the present study, survival, weight gain, feed efficiency, and the protein efficiency ratio of fish fed diets containing up to $14 \%$ DDG were not statistically different in all groups. The present findings indicated that DDG from rice and/or wheat flour could be a useful candidate ingredient in feed for rockfish. These results may be due to an improvement in digestibility as well as a removal of anti-nutritional factors of DDG by means of fermentation. Seo et al. (2011) suggested that nutrient value could possibly be increased over the fermentation period through different microbial activities. During production of DDG from rice, yeasts are used to facilitate the fermentation process. DDG contains a substantial amount of yeast cells (Zhou et al., 2010), which are rich in protein, B-complex vitamins and $\beta$-glucans. These yeast cells could improve the nutritional quality of DDG in the diet of juvenile rockfish.

Lim et al. (2007) reported that different levels of corn-based DDG did not significantly influence the hematological parameters of the Nile tilapia. Similar results were obtained for the hematological parameters of juvenile rockfish in the present study. Rockfish fed diets containing DDG did not significantly differ among the treatments in terms of the body proximate composition. Earlier studies with Nile tilapia (Li et al., 2011) and rainbow trout (Barnes et al., 2012) demonstrated that whole-body proximate composition was not significantly affected by dietary levels of DDG. The successful inclusion of DDG in the diet of juvenile rockfish is probably associated with the nutritional components that arise during fermentation 
by $A$. oryzae and yeasts of rice and/or wheat flour.

The antioxidant activity of an extract can be specified more accurately by assessing the scavenging activities on DPPH, hydroxyl, and alkyl radicals, using an ESR spin-trapping technique. A positive correlation has been reported between free radical scavenging activity and total phenolic compounds (Siriwardhana et al., 2003; Heo et al., 2005). Velioglu et al. (1998) reported that a highly significant relationship existed between total phenols and antioxidant activity for methanolic extracts of fruits, vegetables, and grain products. DPPH is a stable free radical, which accepts an electron or hydrogen radical to become a stable diamagnetic molecule. DPPH has been widely used to examine the free radical scavenging effect of various natural plants and vegetable extracts as antioxidants (Yen and Chen, 1995; Matsukawa et al., 1997; Yamaguchi et al., 1998). To our knowledge, no information is available on the scavenging activities of DDG as a feed ingredient for fish. Kim and Lee (2008) reported that DPPH free radical scavenging activity increased gradually with an increase in dietary Ecklonia cava for juvenile olive flounder. Kim et al. (2010) also reported that DPPH radical scavenging activity was gradually increased by the increment of dietary Meju in juvenile olive flounder. The hydroxyl radical is the main reactive oxygen species, causing various biological damages as well as initiating lipid peroxidation. Heo et al. (2005) demonstrated positive effects against hydroxyl radicals using $E$. cava enzymatic extract. Alkyl radicals were assessed using ESR, a technique for the identification of free radicals. Park et al. (2005) reported alkyl radical scavenging effects and noticed positive impacts using Sargassum thunbergii enzymatic extract. In the present study, the DPPH radical scavenging activity in the plasma of rockfish fed the DDG-RW14 diet increased with increasing dietary content of DDG, but the liver of rockfish did not differ among all groups. The hydroxyl radical scavenging activity in the plasma of rockfish did not differ among all groups, but activity in the liver of rockfish increased with increasing dietary content of DDG from rice and/or wheat flour. The alkyl radical scavenging activity in the plasma of rockfish was not different compared with that of the control group, but the liver of rockfish fed the DDG-R7 diet showed a significant increase in comparison to the control group. The increased radical scavenging activity with the addition of dietary DDG from rice and/or wheat flour in the present study seems to be related to the higher concentrations of phenolic compounds, thereby improving DPPH, hydroxyl, and alkyl radical scavenging activities within the plasma and liver of juvenile rockfish.

The results of this experiment suggest that DDG is a suitable ingredient to replace wheat flour. DGG could be used at a rate of up to $14 \%$ in the diet without incurring any negative effects on growth performance, while reducing the cost of feed formulation for juvenile rockfish.

\section{Acknowledgements}

This research was supported by the Fishery Commercialization Technology Development Program (110077-3) funded by Ministry of Oceans and Fisheries in Korea.

\section{References}

Association of Official Analytical Chemists. 1995. Official Methods of Analysis of the Association of Official Analytical Chemists. 16th ed. Association of Official Analytical Chemists, Arlington, VA, US.

Barnes ME, Brown ML and Rosentrater KA. 2012. Initial observations on the inclusion of high protein distillers dried grain into rainbow trout diets. Open Fish Sci J 5, 21-29. http://dx.doi.org/10.2174/18 74401X01205010001.

Belyea RL, Rausch KD and Tumbleson ME. 2004. Composition of corn and distillers dried grains with solubles from dry grind ethanol processing. Bioresour Technol 94, 293-298. http://dx.doi. org/10.1016/j.biortech.2004.01.001.

Borgeson TL, Racz VJ, Wilkie DC, White LJ and Drew MD. 2006. Effect of replacing fishmeal and oil with simple or complex mixtures of vegetable ingredients in diets fed to Nile tilapia (Oreochromis niloticus). Aquac Nutr 12, 141-149. http://dx.doi.org/10.1111/ j.1365-2095.2006.00394.x.

Canella M, Bernardi A and Marghinotti D. 1984. Improvement of germinated sunflower meal by fermentation. J Food Sci Technol 17, 314-318.

Cheng ZJ and Hardy RW. 2004. Nutritional value of diets containing distiller's dried grain with solubles for rainbow trout, Oncorhynchus mykiss. J Appl Aquac 15, 101-113. http://dx.doi.org/10.1300/ J028v15n03_08.

Chevanan N, Rosentrater KA and Muthukumarappan K. 2010. Effects of processing conditions on single screw extrusion of feed ingredients containing DDGS. Food Bioprocess Technol 3, 111-120. http://dx.doi.org/10.1007/s11947-008-0065-y.

Coyle SD, Mengel GJ, Tidwell JH and Webster CD. 2004. Evaluation of growth, feed utilization, and economics of hybrid tilapia, Oreochromis niloticus $\times$ Oreochromis aureus, fed diets containing different protein sources in combination with distillers dried grains with solubles. Aquac Res 35, 365-370. http://dx.doi.org/10.1111/ j.1365-2109.2004.01023.x.

Cromwell GL, Herkelman KL and Stahly TS. 1993. Physical, chemical and nutritional characteristics of distillers dried grains with solubles for chicks and pigs. J Anim Sci 71, 679-686.

De Godoy MRC, Bauer LL, Parsons CM and Fahey GC Jr. 2009. Select corn coproducts from the ethanol industry and their potential as ingredients in pet foods. J Anim Sci 87, 189-199. http://dx.doi. org/10.2527/jas.2007-0596.

Duncan DB. 1955. Multiple range and multiple $F$-tests. Biometrics 11, 1-42. http://dx.doi.org/10.2307/3001478.

Heo SJ, Park PJ, Park EJ, Kim SK and Jeon YJ. 2005. Antioxidant activity of enzymatic extracts from a brown seaweed Ecklonia cava by 
electron spin resonance spectrometry and comet assay. Eur Food Res Technol 221, 41-47. http://dx.doi.org/10.1007/s00217-0051187-3.

Hiramoto K, Johkoh H, Sako K and Kikugawa K. 1993. DNA breaking activity of the carbon-centered radical generated from 2,2'-azobis-(2amidinopropane)-hydrochloride (AAPH). Free Radic Res Commun 19, 323-332. http://dx.doi.org/10.3109/10715769309056521.

Karunasagar I. 2012. Guest editor's note on the special issue of Indian Journal of Virology: viruses of cultured aquatic animals in the Asia-Pacific region. Indian J Virol 23, 87. http://dx.doi. org/10.1007/s13337-012-0107-y.

Kiers JL, Van Laeken AEA, Rombouts FM and Nout MJR. 2000. In vitro digestibility of bacillus fermented soya bean. Int J Food Microbiol 60, 163-169. http://dx.doi.org/10.1016/S0168-1605(00)00308-1.

Kim SS and Lee KJ. 2008. Effects of dietary kelp (Ecklonia cava) on growth and innate immunity in juvenile olive flounder Paralichthys olivaceus (Temminck et Schlegel). Aquac Res 39, 1687-1690. http://dx.doi.org/10.1111/j.1365-2109.2008.02046.x.

Kim SS, Pham MA, Kim KW, Son MH and Lee KJ. 2010. Effects of microbial fermentation of soybean on growth performances, phosphorus availability, and antioxidant activity in diets for juvenile olive flounder (Paralichthys olivaceus). Food Sci Biotechnol 19, 1605-1610. http://dx.doi.org/10.1007/s10068-010-0227-3.

Li M and Robinson E. 2007. Use of distillers dried grain with soluble in channel catfish diets. In: 31st Fish Feed and Nutrition Workshop. Auburn University, Auburn, Alabama, US.

Li MH, Robinson EH, Oberle DF and Lucas PM. 2010. Effects of various corn distillers by-products on growth, feed efficiency, and body composition of channel catfish, Ictalurus punctatus. Aquac Nutr 16, 188-193. http://dx.doi.org/10.1111/j.1365-2095.2009.00650.x.

Li E, Lim C, Cai C and Klesius PH. 2011. Growth response and resistance to Streptococcus iniae of Nile tilapia, Oreochromis niloticus, fed diets containing different levels of wheat distiller's dried grains with solubles with or without lysine supplementation. Anim Feed Sci Technol 170, 246-255. http://dx.doi.org/10.1016/j.anifeedsci.2011.09.002.

Lim C, Garcia JC, Yildirim-Aksoy M, Klesius PH, Shoemaker CA and Evans JJ. 2007. Growth response and resistance to Streptococcus iniae of Nile tilapia, Oreochromis niloticus, fed diets containing distiller's dried grains with solubles. J World Aquac Soc 38, 231237. http://dx.doi.org/10.1111/j.1749-7345.2007.00093.x.

Lim C, Yildirim-Aksoy M and Klesius PH. 2009. Growth response and resistance to Edwardsiella ictaluri channel catfish, Ictalurus punctatus, fed diets containing distiller's dried grains with solubles. J World Aquac Soc 40, 182-193. http://dx.doi.org/10.1111/j.17497345.2009.00241.x.

Matsukawa R, Dubinsky Z, Kishimoto E, Masaki K, Masuda Y, Takeuchi T, Chihara M, Yamamoto Y, Niki E and Karube I. 1997. A comparison of screening methods for antioxidant activity in seaweeds. J Appl Phycol 9, 29-35. http://dx.doi. org/10.1023/A:1007935218120.

Nanjo H, Adachi H, Aketa M, Mizoguchi T, Nishihara T and Terada T. 1995. The role of cysteine in the alteration of bovine liver dihydrodiol dehydrogenase 3 activity. Biochem J 310, 101-107.
Park PJ, Heo SJ, Park EJ, Kim SK, Byun HG, Jeon BT and Jeon YJ. 2005. Reactive oxygen scavenging effect of enzymatic extracts from Sargassum thunbergii. J Agric Food Chem 53, 6666-6672. http://dx.doi.org/10.1021/jf050582.

Rahman MM, Choi J and Lee SM. 2013. Influences of dietary distillers dried grain level on growth performance, body composition and biochemical parameters of juvenile olive flounder (Paralichthys olivaceus). Aquac Res. Adavanced online publication. http:// dx.doi.org/10.1111/are.12157.

Randall KM and Drew MD. 2010. Fractionation of wheat distiller's dried grains and solubles using sieving increases digestible nutrient content in rainbow trout. Anim Feed Sci Technol 159, 138-142. http://dx.doi.org/10.1016/j.anifeedsci.2010.05.011.

Reddy NR and Pierson MD. 1994. Reduction in antinutritional and toxic components in plant foods by fermentation. Food Res Int 27, 281290. http://dx.doi.org/10.1016/0963-9969(94)90096-5.

Robinson EH and Li MH. 2008. Replacement of soybean meal in channel catfish, Ictalurus punctatus, diets with cottonseed meal and distiller's dried grains with solubles. J World Aquac Soc 39, 521-527. http://dx.doi.org/10.1111/j.1749-7345.2008.00190.x.

Rosen GM and Rauckman EJ. 1984. Spin trapping of superoxide and hydroxyl radicals. Methods Enzymol 105, 198-209. http://dx.doi. org/10.1016/S0076-6879(84)05026-6.

Saunders JA and Rosentrater KA. 2009. Survey of US fuel ethanol plants. Bioresour Technol 100, 3277-3284. http://dx.doi. $\operatorname{org} / 10.1016 /$ j.biortech.2009.01.071.

Schaeffer TW, Brown ML and Rosentrater KA. 2009. Performance characteristics of Nile tilapia (Oreochromis niloticus) fed diets containing graded levels of fuel-based distillers dried grains with solubles. J Aquac Feed Sci Nutr 1, 78-83. http://dx.doi.org/10.3923/joafsnu.2009.78.83.

Schaeffer TW, Brown ML and Rosentrater KA. 2011. Effects of dietary distillers dried grains with solubles and soybean meal on extruded pellet characteristics and growth responses of juvenile yellow perch. N Am J Aquac 73, 270-278. http://dx.doi.org/10.1080/152 22055.2011.593461.

Seo JY, Shin IS and Lee SM. 2011. Effect of dietary inclusion of various plant ingredients as an alternative for Sargassum thunbergii on growth and body composition of juvenile sea cucumber Apostochopus japonicas. Aquac Nutr 17, 549-556. http://dx.doi. org/10.1111/j.1365-2095.2010.00849.x.

Siriwardhana N, Lee KW, Kim SH, Ha JW and Jeon YJ. 2003. Antioxidant activity of Hizikia fusiformis on reactive oxygen species scavenging and lipid peroxidation inhibition. Food Sci Technol Int 9, 339-346. http://dx.doi.org/10.1177/1082013203039014.

Skrede A and Nes IF. 1988. Slaughterhouse by-products preserved by Lactobacillus plantarum fermentation as feed for mink and foxes. Anim Feed Sci Technol 20, 287-298. http://dx.doi. org/10.1016/0377-8401(88)90003-X.

Thompson KR, Rawles SD, Metts LS, Smith RG, Wimsatt A, Gannam AL, Twibell RG, Johnson RB, Brady YJ and Webster CD. 2008. Digestibility of dry matter, protein, lipid, and organic matter of two fish meals, two poultry by-product meals, soybean meal, and distiller's dried grains with solubles in practical diets for sunshine 
bass, Morone chrysops $\times$ M. saxatilis. J World Aquac Soc 39, 352363. http://dx.doi.org/10.1111/j.1749-7345.2008.00174.x.

Velioglu YS, Mazza G, Gao L and Oomah BD. 1998. Antioxidant activity and total phenolics in selected fruits, vegetables and grain products. J Agric Food Chem 46, 4113-4117. http://dx.doi.org/10.1021/ jf9801973.

Webster CD, Tidwell JH, Goodgame LS and Johnsen PB. 1993. Growth, body composition, and organoleptic evaluation of channel catfish fed diets containing different percentages of distiller's grain with solubles. Prog Fish-Cult 55, 95-100. http://dx.doi. org/10.1577/1548-8640(1993)055<0095:GBCAOE > 2.3.CO;2.

Wu YV, Rosati RR and Brown PB. 1997. Use of corn-derived ethanol co-products and synthetic lysine and tryptophan for growth of tilapia (Oreochromis niloticus) fry. J Agric Food Chem 45, 21742177. http://dx.doi.org/10.1021/jf960880u..

Yamaguchi T, Takamura H, Matoba T and Terao J. 1998. HPLC method for evaluation of the free radical-scavenging activity of foods by using 1,1-diphenyl-2-picrylhydrazyl. Biosci Biotechnol Biochem 62, 1201-1204. http://dx.doi.org/10.1271/bbb.62.1201.

Yamamoto M, Saleh F and Hayashi K. 2004. A fermentation method to dry and convert shochu distillery by-product to a source of protein and enzymes. J Poult Sci 41, 275-280. http://dx.doi.org/10.2141/ jpsa.41.275.

Yen GC and Chen HY. 1995. Antioxidant activity of various tea extracts in relation to their antimutagenicity. J Agric Food Chem 43, 27-32. http://dx.doi.org/10.1021/jf00049a007.

Zhou P, Zhang W, Davis DA and Lim C. 2010. Growth response and feed utilization of juvenile hybrid catfish fed diets containing distiller's dried grains with solubles to replace a combination of soybean meal and corn meal. N Am J Aquac 72, 298-303. http:// dx.doi.org/10.1577/A10-002.1. 